\title{
SPACE, RACE, BODIES - A CONFERENCE THEME, A TIMELY REMINDER ${ }^{1}$
}

\section{Moana Jackson ${ }^{2}$}

The conference hosted at Otago University on the theme 'Space, Race, Bodies' is appropriate in a colonised and colonising society. It is especially apt in Aotearoa where the dispossession of iwi and hapū (Indigenous nations and peoples) since 1840 is still cloaked in the misbelief that colonisation was somehow 'better' here than anywhere else. Indeed, the idea that because of the so-called 'honour of the Crown', the taking of the lands, lives, and power of Māori was somehow a flawed exercise in civilisational uplift - rather than a violent and duplicitous genocide - has become the origin story of Kiwi culture.

Such a presumption is, of course, a contradiction in terms, because there is never honour in the dishonour of dispossession, yet it persists as a kind of pulp fiction in which the history of colonisation has actually become a colonisation of history itself. The Treaty of Waitangi became the symbol of Crown honour and good faith, even as its solemn promises were - and still are - misinterpreted, redefined, or denied. And the racism which was always fundamental in Europe's dispossession of Indigenous Peoples has been perhaps its most redefined and denied reality. Frantz Fanon's comment that '... [i]n reality a colonial country is a racist country' $(1964,39-40)$ has been a discomfiting truth applied to others more than a lens through which to understand and acknowledge what has happened here.

If racism is ever recognised, it is either seen as an individual aberration rather than a systemic fact, an exception to the rule of a benevolent 'settlement', rather than an acceptance of the fact that in the end colonisation was constructed on the racist belief that so-called White, civilised people in Europe were innately superior and therefore had the right to dispossess non-White 'uncivilised' peoples who were inferior. Space and bodies were key to that dangerous and violent belief.

For colonisation is a race-based process. It has always been influenced by many 
different perceptions, but the idea of race, and the dread of racism, have coloured everything about it. They are the miro matua, or main threads, in all of its design, and the constant presence through which the colonisers compounded other ancient prejudices and hatreds such as sexism and religious intolerance. They are also the baseline upon which all of its ambitions for wealth and a 'better life' were achieved, because whether the colonisers wanted to reproduce the old class and capitalist order of Europe, or to create the equality of a classless and more moral economy, they both depended upon Indigenous Peoples becoming a racialised and dispossessable underclass. Racism was the starting point for defining both the exploitability and inequality.

The thought of racism was as unfathomable to our people as colonisation, because we could never see relationships in the way it did. We were not immune from the impatience that can slide into intolerance, but racism's special kind of individual and group discrimination was new to us because we had no sense that whakapapa (genealogical heritage) could be so demeaned or a people's worth inferred from something as ephemeral as their physical appearance. At its most primal, it is a duplicitous sham which replaces the normal curiosity people have about the different and unknown with a condescending unwillingness to know the truth, and at its most dangerous, it is an obscene stripping away of human dignity that is more damaging than disdain and more hurtful when it is denied. Its complex history and meaning developed in two interrelated but distinct forms which may be called the racism of the body and the racism of space.

The racism of the body is evident in the archive of inferiority that has been applied to Indigenous Peoples, including Māori. Whether it is the ancient depiction of a warrior race, or the modern profiling of young Māori as potential shoplifters because they 'look' criminal, it has been a desired conclusion in search of a fact to prove it. Its contempt has bred a familiarity that has proved to be as alluring and persuasive as it has been destructive. Like a bad novel, it has conveyed a kind of truth - even though it has all been made up.

Most of its stories are well known, and all of them are tedious and hurtful to revisit. The 'thinkers' who first thought of them, and the extremists who have taken advantage of them, are part of a long and squalid history marked most of all by their idea of the chains of being. It started in the divine reason, when Europeans began to ask why all of God's children were not the same colour, and turned the hierarchies leading to heaven into categories of racial difference. The most commonly used justification was found in the Biblical story of Noah and his sons, where God placed a permanent blight on the skin of 
Ham's descendants after he had seen his father naked. Those people, who were consigned to that coloured-up condition, became '... the wandering stars to whom is reserved the blackness of darkness forever' (Jude 1:13). Their darker hue was then contrasted with the fairer Europeans, who were the most 'beautiful race of men' because they had been washed clean in the blood of Jesus and were closer to God as a result.

The chains of race became more diverse as enlightenment rationalists began to classify peoples in the same way that they were labelling species of plants and animals. Some of the new classification systems featured pictures that had Europeans ensconced in splendid isolation from other different groups of 'Indians' sitting lower down the ladder with sloths or snakes. Others associated colour-coding with certain skills, and placed the 'White' Europeans in the upper levels because of the greater imaginative and technical ability they were meant to have. The chains rainbowed down according to the characteristics that went with pigmentation - the 'yellows' could be quite high but kept slipping because they were feeble and passive, the 'reds and browns' were lower since they were nomadic and savage, and the 'blacks' were always stuck in obscurity because they had an overall incompetence. Sometimes the less black races were moved up and down according to their relationship with Europe, at the time while a few oppressed Europeans such as the Irish and the Jews were defined as a darker shade of pale. But those who were really White had an apparent destiny to rule the world because they alone could illumine it with their intelligence, reason and courage.

By the eighteenth century, racism had become a pseudo-science that made Indigenous Peoples the lab rats of Europe. Bodies were 'pinned like butterflies to a wall', and forlorn samples of amputated limbs, pickled genitals, and mounted noses were scanned as experts tried to establish everything from a lack of sexual control to an inability to smell perfume. Phrenologists and craniometrists cut open skulls and filled them with gunshot powder or seed to test the correlation between head weight and IQ. Navigators who understood the sea suddenly decided they could understand foreign people, and filled their ship's logs with seemingly objective insights into the degrees of inbred violence or immorality they encountered. Botanists believed that their skill in identifying plant species enabled them to make judgements about Indigenous character and history, and ethnographers struggling for credibility with their new 'science' made incredible judgements on people without often knowing the language they spoke. Elsdon Best summed up these egregious lies in this country with his presumption that '... [u]ncivilized folk, such as our Maori, may not do any great amount of thinking' (1995 [1924], 31). 
The 'racism of space' is the prejudice which defines the values and institutions of the colonisers as being inherently better than any others - it is a privileging of European power and reality. It began with the ethnocentric chauvinism people often have about their own way of doing things, and became a racist lie when it was presumed that every European reality was actually a 'race-less' phenomenon that somehow existed beyond or outside of its unique cultural and racial origins. In effect, it 'e-raced' and 'de-cultured' European history until it floated in what one British governor called an 'independently supreme' condition, where quite distinct cultural artefacts such as its political organisation and its definitions of law and land were redefined as 'universal'. It then racialised the space in which Indigenous Peoples lived, by declaring it inferior and imposing upon it the institutions and values of the coloniser.

In that sense the racism of space is a prejudice pretending to be neutral. It was thought into being with the same hateful intolerance as the racism of the body, but its conclusion that everything European was universal and 'normal' invisible-ised the race-base of its presumptions and made them seem right as well as better. Its purported universalism then masked the brutal racism involved in imposing a colonising system, and thus created an almost unrecognised domination that was nevertheless just as oppressive as that of the battered body: a sly behind-your-back racism in which the statement that 'there must be one (colonising) law for all' is as pernicious in its racist put-down as one that is in your face.

The racist privileging of that alleged universality was imposed everywhere in colonisation, but its most important stories were those to do with power and land. They elevated notions such as sovereignty and property into a position of independent supremacy, but in doing so confused the very human - and truly universal - ideals of democracy and relationships with the land, with the very specific institutions and values that were developed in Europe to give expression to them. It was as if the colonisers became racist in the simple act of being themselves, and it makes the current tiresome claims about 'Māori privilege' much more than an individual racist trope - they are, in fact, a defence of White supremacy and the space within which colonisers can protect the wealth and wealth and power they now take for granted.

In many ways the criminal justice system, and especially prisons, merge the racism of the body and space together. For the young Màori man or woman in a prison cell cannot be isolated from the historic profiling of their bodies as inherently or potentially criminal, and the system which incarcerates them cannot be isolated from the space the colonisers have created to define their 
power to control those who threaten their 'law and order'. The fact that Māori men make up fifty-two per cent of the prison population, and Māori women sixty-four per cent, is a shameful statistic that reflects and exhibits Fanon's other harsh but accurate statement that ${ }^{\prime} . .$. [r] ace prejudice ... obeys a flawless logic. A country that lives, draws its sustenance from the exploitation of other peoples, makes those people inferior' $(1964,40-1)$. In that context, abolishing prisons is not just a move towards a more humane way of dealing with harm and protecting those who have been harmed - it is also a step away from the racism which underpins it and the colonising society which benefits from it. In itself, that is therefore a de-colonising act.

The papers delivered at the conference ranged across much broader fields than just criminal 'justice', and each one was a brave and imaginative decolonising act. In their own way, they reclaimed the beauty of the body and the safety of a space free from the hurt of colonisation and racism.

\section{NOTES}

1 See Jackson, Brown-Davis, and Sykes (2016) for their conference presentation; this, and podcasts and transcripts from other keynote speakers, are available on the Space, Race, Bodies website: www.spaceracebodies.com.

2 Moana Jackson is a New Zealand Mãori lawyer specialising in Treaty of Waitangi and constitutional issues. He is of Ngāti Kahungunu and Ngāti Porou descent. In 1988 he co-founded (with now Judge Caren Fox) the first Māori Community Law Centre, Ngā Kaiwhakamārama i ngā Ture (the Māori Legal Service). He also teaches in the Māori Law and Philosophy degree programme at Te Wānanga o Raukawa, the largest Indigenous tertiary college in the world. Moana graduated in Law from Victoria University of Wellington; was Director of the Māori Law Commission; was appointed Judge on the International People's Tribunal in 1993 and has since then sat on hearings in Hawai' i, Canada, and Mexico. He was appointed Visiting Fellow at the Victoria University Law School in 1995, and was elected Chair of the Indigenous People's Caucus of the United Nations Working Group on the Rights of Indigenous Peoples. Moana wrote about restorative justice in a highly acclaimed report in 1988, titled 'Māori and the Criminal Justice System'. Since 2011 he has co-chaired, with Professor Margaret Mutu, the Independent Iwi working Group on Constitutional Transformation, which has held over 300 hui (meetings) around the country discussing the need for Treatybased constitutional change. The Report of the Working Group was released on Waitangi Day 2016. 
Commentary $\cdot$ Jackson

REFERENCES

Best, Eldson. 1995 [1924]. Māori Religion and Mythology: Being an Account of the Cosmogony, Anthropogeny, Religious Beliefs and Rites, Magic and Folk Lore of the Māori Folk of New Zealand. Wellington: Museum of New Zealand, Te Papa Tongarewa.

Fanon, Frantz. 1964. Toward the African Revolution: Political Essays. Translated by Haakon Chevalier. New York: Grove Press.

Jackson, Moana, Brown-Davis, Sina, and Annette Sykes. 2016. 'Decarceration, Not Prison; Justness, not Justice; Constitutional Transformation, Not Treaty Settlements. Paper presented at Space, Race, Bodies II: Sovereignty and Migration in a Carceral Age, Dunedin, University of Otago, May 6. 